\title{
Analisis Penerapan PSAP Nomor 13 Tentang Penyajian Laporan Keuangan Badan Layanan Umum Pada RSUP Prof. Dr. R. D. Kandou Manado
}

\author{
RIANI ISYE KAWENAS ${ }^{1}$, LINTJE KALANGI ${ }^{2}$, LINDA LAMBEY ${ }^{3}$
}

\author{
${ }^{1,2,3}$ Program Magister Akuntansi, Fakultas Ekonomi dan Bisnis Universitas Sam Ratulangi \\ email: ria_kwnas@ymail.com ${ }^{1}$, lintjekalangi@yahoo.com ${ }^{2}$, lindalambey@yahoo.com ${ }^{3}$
}

\begin{abstract}
This study aims to analyze the presentation of financial statements in public service agencies at the RSUP Prof. Dr. R. D. Kandou in accordance to PSAP Number 13. This is a qualitative exploratory research. Data were obtained by in-depth interviews, observation and documentation study. Key informants were determined by purposive sampling in order to meet criterias and to obtain accurate and correct information. Triangulation techniques were used to test the validity of data and data sources. The data were transcribed from the interviews transcriptions. The transcriptions were analyzed by analytical methods consisting of finding themes/coding, conceptualizing scientific statements and interpreting them in narrative form. The results show that the presentation of financial statements in public service agencies at the Prof. Dr. R. D. Kandou has implemented or in accordance to PSAP Number 13. However, they do not completely implement it, particularly in recognizing revenue on Operational Cooperation (KSO). In fact, there are some obstacles in preparing the financial statements. Those obstacles are (1) no clear regulation on the definition of KSO, (2) lack of additional rules or technical guidelines to describe the implementation of PSAP Number 13 for KSO, (3) lack of communication from the Ministry of Health to the Hospital resulting in lack of qualified human resources influences the realization target of PNBP and (4) the assessment of hospital performance is influenced by PSAP Number 13. Due to the importance of the work unit to comply with this regulation, it is necessary to strive to support policies to ensure the implementation of PSAP Number 13 is in accordance to the provisions.
\end{abstract}

\section{Keywords: PSAP Number 13, Public Service Board, Regulation, Effect of Implementation}

\begin{abstract}
Abstrak. Penelitian ini bertujuan menganalisis penyajian laporan keuangan badan layanan umum pada RSUP Prof. Dr. R. D. Kandou berdasarkan penerapan PSAP Nomor 13. Penelitian ini menggunakan metode kualitatif dengan pendekatan eksploratori. Data diperoleh melalui teknik wawancara mendalam, observasi dan studi dokumentasi. Informan kunci ditetapkan secara purposive sampling dengan memenuhi kriteria yang ditetapkan untuk mendapatkan informasi yang tepat dan akurat. Teknik triangulasi digunakan untuk menguji validitas data dan sumber data. Data transkrip yang diuraikan dari hasil wawancara dianalisis menggunakan metode analisis yang terdiri dari pemberian tema/coding, konseptualisasi pernyataan ilmiah dan menginterpretasikannya dalam bentuk narasi. Hasil penelitian menunjukkan bahwa penyajian laporan keuangan badan layanan umum pada RSUP Prof Dr. R. D. Kandou berdasarkan PSAP Nomor 13 telah diterapkan, namun belum secara keseluruhan, khususnya dalam mengakui pendapatan atas Kerjasama Operasional (KSO). Dalam penyusunan laporan keuangan masih ditemukan beberapa kendala antara lain (1) belum adanya regulasi yang jelas tentang pengertian KSO, (2) belum tersedianya aturan tambahan atau petunjuk teknis untuk menjabarkan penerapan PSAP Nomor 13 untuk KSO, (3) kurangnya komunikasi dari Kementerian Kesehatan RI kepada Rumah Sakit yang mengakibatkan kurangnya SDM yang memahami dan (4) adanya pengaruh penerapan PSAP Nomor 13 terhadap target realisasi PNBP pengaruh penerapan PSAP Nomor 13 pada penilaian kinerja Rumah Sakit. Karena pentingnya satuan kerja untuk patuh pada regulasi ini maka perlu diupayakan kebijakan pendukung untuk memastikan implementasi PSAP Nomor 13 berjalan sesuai ketentuan.
\end{abstract}

Kata Kunci: PSAP Nomor 13, Badan Layanan Umum, Regulasi, Pengaruh Penerapan.

\section{Pendahuluan}

Dalam mewujudkan pengelolaan keuangan yang baik, pemerintah menetapkan suatu standar, pedoman-pedoman, prinsip-prinsip yang menjadi acuan di setiap organisasi pemerintah dalam penyusunan laporan keuangan. Oleh sebab itu dikeluarkanlah Peraturan Pemerintah (PP) Republik Indonesia (RI) Nomor (No) 71 Tahun 2010 tentang Standar Akuntansi Pemerintahan (SAP) yang kemudian membawa suatu perubahan besar dalam sistem pelaporan keuangan. Penetapan Standar Akuntansi Pemerintahan (SAP) ini didukung dengan adanya struktur Standar Akuntansi Pemerintahan Berbasis Akrual yang disajikan dalam 12 (dua belas) Pernyataan Standar Akuntansi Pemerintahan (PSAP) pada Lampiran I PP 71 Tahun 2010. Namun adanya kedua belas PSAP ini belum menjawab kebutuhan Satuan Kerja yang menganut Pola Pengelolaan Keuangan Badan Layanan Umum.

Menurut PP No. 23 Tahun 2005 Badan Layanan Umum adalah instansi di lingkungan Pemerintah yang dibentuk untuk memberikan pelayanan kepada masyarakat berupa penyediaan barang dan/atau jasa yang dijual tanpa mengutamakan mencari keuntungan dan dalam melakukan kegiatannya 
didasarkan pada prinsip efisiensi dan produktivitas. Pola Pengelolaan Keuangan Badan Layanan Umum (BLU) diatur melalui PP No. 23 Tahun 2005 dan diubah dengan PP No. 74 Tahun 2012. Badan Layanan Umum (BLU) bertujuan untuk meningkatkan pelayanan kepada masyarakat dalam rangka memajukan kesejahteraan umum dan mencerdaskan kehidupan bangsa dengan memberikan fleksibilitas dalam pengelolaan keuangan berdasarkan prinsip ekonomi dan produktivitas, dan penerapan praktek bisnis yang sehat. Pola Pengelolaan Keuangan BLU pada praktiknya diberikan keleluasaan antara lain pengecualian-pengecualian dari pola pengelolaan keuangan pemerintah pada umumnya, misalnya pendapatan yang bisa langsung digunakan untuk belanja BLU tanpa melalui pengesahan oleh BUN/BUD dan melaksanakan investasi jangka pendek. BLU diberi kewenangan untuk melakukan pengelolaan pendapatan, pengelolaan kas, investasi dan penentuan standar biaya pelayanan.

BLU mempunyai posisi ganda sebagai entitas pelaporan maupun entitas akuntansi terkait pelaporan keuangannya. Pertama sebagai entitas pelaporan, BLU wajib memberikan pelaporan yang menyeluruh atas penggunaan seluruh sumber daya yang dikuasai kepada pihak pihak yang berkepentingan, terutama pihak eksternal seperi donatur, auditor eksternal dan lembaga legislatif. Akuntansi dan laporan keuangan BLU sebagai entitas pelaporan diselenggarakan sesuai dengan Standar Akuntansi Keuangan yang diterbitkan oleh asosiasi profesi akuntansi Indonesia (PP 23 Tahun 2005 pasal 26 ayat 2). Kedua sebagai entitas akuntansi, BLU diwajibkan menyusun laporan keuangan yang akan dikonsolidasikan dengan entitas akuntansi yang membawahinya. Jenis laporan yang akan dikonsolidasi ini dilakukan sesuai dengan Standar Akuntansi Pemerintahan (PP 23 Tahun 2005 pasal 27 ayat 7). Sehingga sampai dengan tahun 2016 Satuan Kerja BLU masih diwajibkan menyusun 2 (dua) jenis laporan keuangan yaitu Laporan Keuangan yang mengacu pada Standar Akuntansi Keuangan dan Laporan Keuangan yang mengacu pada Standar Akuntansi Pemerintahan.

Pada tanggal 31 Desember 2014, Menteri Keuangan mengeluarkan Peraturan Menteri Keuangan Nomor 270/PMK.05/2014 tentang Standar Akuntansi Pemerintahan Berbasis Akrual. Dalam pasal 2 dijelaskan bahwa Pemerintah Pusat menerapkan SAP Berbasis Akrual mulai tahun 2015. Penerapan ini diberlakukan terhadap seluruh satuan kerja pemerintah pusat, tanpa terkecuali termasuk satuan kerja badan layanan umum. Dengan berlakunya PMK ini menjadi salah satu alasan utama bagi Komite Standar Akuntansi Pemerintahan (KSAP) untuk melakukan penyederhanaan dalam pelaporan keuangan badan layanan umum, salah satunya adalah dengan menerbitkan suatu PSAP khusus terkait pelaporan BLU. Dengan adanya penyederhanaan ini maka BLU cukup menggunakan SAP dalam menyusun laporan keuangannya dan tidak lagi menyusun laporan keuangan berdasarkan SAK.

Untuk menjawab kebutuhan terkait penyusunan laporan keuangan dari satuan kerja BLU maka pada tanggal 2 Desember 2015 Menteri Keuangan mengeluarkan Peraturan Menteri Keuangan Nomor 217/PMK.05/2015 tentang Pernyataan Standar Akuntansi Pemerintahan Nomor 13 tentang Penyajian Laporan Keuangan Badan Layanan Umum. Dalam Peraturan Menteri Keuangan ini, satuan kerja BLU diwajibkan menggunakan PSAP No. 13 dalam penyusunan Laporan Keuangan Tahun 2016.

RSUP Prof. Dr. R. D. Kandou Manado sebagai satuan kerja BLU memiliki kewajiban untuk mematuhi aturan penyusunan laporan keuangan sesuai PSAP No. 13 yang ditetapkan dalam PMK Nomor 217/PMK.05/2015. Dalam ketentuan tersebut ditetapkan bahwa laporan keuangan sesuai PSAP No. 13 wajib dilaksanakan pada penyusunan Laporan Keuangan Tahun 2016. Hal ini didukung oleh PMK No. 220/PMK.05/2016 pasal 11 yang menyebutkan bahwa penyusunan laporan keuangan BLU mulai dilaksanakan pada penyusunan dan penyampaian laporan keuangan BLU tahun 2016. Pada tanggal 10 Maret 2017, Menteri Keuangan RI mengeluarkan Peraturan Menteri Keuangan RI No. 42/PMK.05/2017 tentang perubahan atas PMK No. 220/PMK.05/2016 tentang sistem akuntansi dan pelaporan keuangan badan layanan umum yang mengubah ketentuan pasal II dimana dijelaskan bahwa ketentuan mengenai sistem akuntansi dan pelaporan keuangan BLU yang diatur dalam Peraturan Menteri Keuangan Nomor 220/PMK.05/2016 tentang sistem akuntansi dan pelaporan keuangan Badan Layanan Umum beserta perubahannya paling lambat digunakan dalam rangka penyusunan dan penyampaian Laporan Keuangan BLU tahun 2017.

Hal baru yang diatur dalam PSAP Nomor 13 yaitu mengenai pengakuan pendapatan secara netto pada Kerjasama Operasional (KSO) sehingga dalam penelitian ini, KSO menjadi pusat pembahasan yang digali lebih mendalam. Mengingat pentingnya mematuhi ketentuan dalam PSAP Nomor 13 dan karena banyaknya KSO yang dilaksanakan oleh RSUP Prof. Dr. R. D. Kandou Manado maka penelitian ini bertujuan untuk memperoleh gambaran yang jelas tentang penyusunan dan penyampaian laporan keuangan dan kesesuaiannya dengan PSAP Nomor 13, dan menganalisis 
kendala-kendala yang dihadapi beserta upaya-upaya yang harus dilakukan untuk mengatasi kendalakendala dalam penerapan PSAP Nomor 13 demi mencapai penyajian laporan keuangan Badan Layanan Umum yang baik.

Tujuan penelitian ini untuk: 1) Menganalisis penerapan PSAP Nomor 13 dalam penyusunan dan penyampaian laporan keuangan di RSUP Prof. Dr. R.D. Kandou pada tahun 2017; 2) Menganalisis kendala-kendala yang menghambat penerapan PSAP Nomor 13 pada penyusunan dan penyampaian laporan keuangan di RSUP Prof. Dr. R.D. Kandou pada tahun 2017; 3) Menganalisis upaya yang dilakukan oleh RSUP Prof. Dr. R.D. Kandou agar penyusunan dan penyampaian laporan keuangan sesuai dengan PSAP Nomor 13.

\section{Model Analisis}

Model analisis pada penelitian ini dimulai dengan melihat fenomena yang terjadi pada pengelolaan aset daerah dan menentukan topik penelitian. Selanjutnya melakukan pengumpulan data dengan teknik wawancara dan didukung dengan studi dokumentasi dan observasi. Langkah berikutnya yaitu mengolah data, menguji keabsahan data dan menyusun laporan hasil penelitian.

Gambar 1

Model Analisis

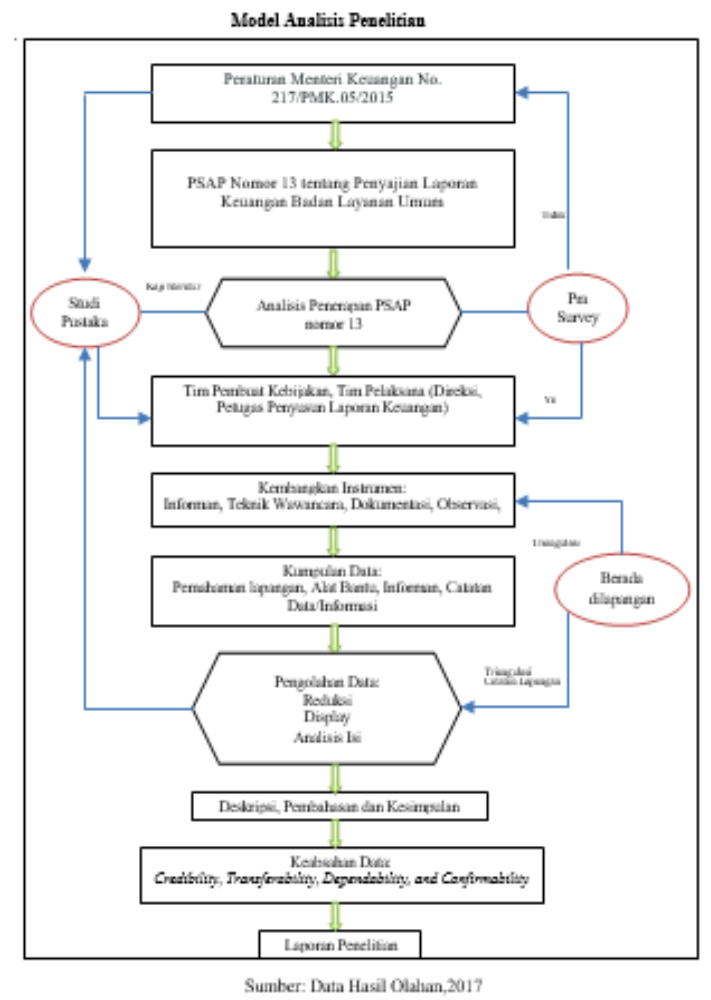

\section{Metode Penelitian}

Metode penelitian kualitatif dengan pendekatan eksploratori dipilih oleh peneliti untuk mendapatkan informasi yang lebih lengkap, mendalam sampai pada titik dimana informasi-informasi yang didapatkan memiliki kesamaan maksud dan/atau makna, kredibel dan bermakna dengan melakukan wawancara kepada individu yang terlibat dalam aktivitas dan proses penyusunan laporan. Selain itu, peneliti bisa menemukan lebih jauh dan mendalam terhadap kemungkinan-kemungkinan lain dari permasalahan yang diteliti.

Teknik Analisis Data yang digunakan dalam penelitian ini adalah Teknik Analisis Model Milles dan Huberman dalam Sugiyono (2015:85) yang terdiri atas: data reduction, data display dan drawing conclusion/verification yang dilakukan secara interaktif dan berlangsung secara terus menerus sampai tuntas, sehingga datanya mencapai jenuh. Penulis melakukan pengumpulan data sesuai dengan pedoman wawancara yang telah dipersiapkan, adapun data-data yang diambil adalah Surat Keputusan Direktur Utama tentang Tim Penyusun Laporan Keuangan pada RSUP Prof. Dr. R. D. Kandou dan dokumen-dokumen sumber sebagai data pendukung laporan keuangan serta laporan keuangan akhir 
dari RSUP Prof. Dr. R. D. Kandou. Dalam penelitian tentu saja akan mendapatkan data yang banyak dan relatif beragam dan bahkan sangat rumit. Itu sebabnya, perlu dilakukan analisis data melalui reduksi data. Data yang diperoleh dalam penelitian ini nantinya ditulis dalam bentuk laporan atau data yang terperinci. Laporan yang disusun berdasarkan data yang diperoleh direduksi, dirangkum, dipilih hal-hal yang pokok, difokuskan pada hal-hal yang penting. Pereduksian data dilakukan dengan cara mengambil intisari jawaban responden yang terkait dengan pokok pembahasan yang tertuang dalam pertanyaan interview. Intisari dari jawaban responden yang terdapat dalam interviewtranscription kemudian dituangkan dalam bentuk pattern atau pola jawaban.

Tujuan utama dalam penelitian kualitatif adalah pada temuan. Bila ini ditemukan saat melakukan penelitian, maka akan dikembangkan sehingga dapat mengungkapkan hal-hal baru terkait topik penelitian. Hal hal baru yang dimaksud adalah temuan menyangkut variable ataupun ide pokok yang belum ada ataupun yang masih sedikit pembahasannya dalam dunia literatur. Langkah selanjutnya sesudah mereduksi data adalah menyajikan data (Data Display). Dalam penelitian ini, display data disajikan dalam bentuk naratif yang dikutip dari interview transcription dan tabel. Tahap terakhir dari seluruh kegiatan analisis data kualitatif model Miles \& Huberman adalah kesimpulan. Pada tahap ini melakukan meaning atau yang disebut interpretasi data, yaitu melakukan kegiatan menghubungkan, membandingkan dan mendeskripsikan data sesuai fokus masalah untuk diberi makna. Pemberian makna ini dilakukan juga konseptualisasi pernyataan ilmiah yang akan menjadi bahan simpulan penelitian. Kesimpulan yang disajikan harus menjurus kepada jawaban dari pertanyaan penelitian yang mengungkap "apa" dan "bagaimana" temuan-temuan yang didapat dari kegiatan penelitian tersebut.

Mengacu pada metode dan teknik analisis diatas, maka langkah-langkah analisis data yang dikembangkan pada penelitian ini adalah sebagai berikut.

1. Data dari wawancara, dokumentasi dan observasi diorganisir kesamaan dan perbedaannya sesuai dengan rumusan masalah dan pertanyaan penelitian.

2. Data yang sudah diorganisir ditentukan temanya.

3. Mencari keterkaitan antara tema.

4. Interpretasi atas semua temuan sesuai dengan keterkaitan antar tema dengan menggunakan teori/konsep yang relevan.

Penelitian ini menggunakan uji keabsahan data dalam penelitian kualitatif menurut Sugiyono (2015:117) yang meliputi: 1) Uji kredibilitas data atau kepercayaan terhadap data hasil penelitian kualitatif dalam penelitian ini dilakukan dengan triangulasi dan member check. 2) Uji validitas eksternal (transferability). Transferability ini merupakan validitas eksternal yang menunjukkan derajat ketepatan atau dapat diterapkannya hasil penelitian ke populasi dimana sampel tersebut diambil. Nilai transfer ini berkenaan dengan pertanyaan, sejauh mana hasil penelitian dapat diterapkan atau digunakan dalam situasi lain. Oleh karena itu, supaya orang lain dapat memahami hasil penelitian kualitatif sehingga ada kemungkinan untuk menerapkan hasil penelitian tersebut, maka dalam membuat laporan harus memberikan uraian yang rinci, jelas, sistematis dan dapat dipercaya; 3) Uji reliabilitas (dependability). Suatu penelitian yang reliabel adalah apabila orang lain dapat mengulangi/mereplikasi proses penelitian tersebut. Dalam penelitian kualitatif, uji dependability dilakukan oleh pembimbing mulai dari memeriksa keseluruhan aktifitas penelitian, mulai dari menentukan masalah/ fokus, menentukan sumber data, menentukan analisis data, melakukan uji keabsahan data dan sampai pada pembuatan kesimpulan/ laporan akhir; 4) Uji objektivitas (confirmability). Penelitian dikatakan objektif bila hasil penelitian telah disepakati oleh banyak orang. Dalam penelitian kualitatif, uji confirmability mirip dengan uji dependability, sehingga pengujiannya dapat dilakukan secara bersamaan. Menguji confirmability berarti menguji hasil penelitian, dikaitkan dengan proses yang dilakukan. Bila hasil penelitian merupakan fungsi dari proses penelitian yang dilakukan, maka penelitian telah memenuhi standar confirmability.

\section{Analisis dan Pembahasan}

Penelitian dilakukan selama 3 (tiga) bulan sejak bulan Juli sampai September 2017 dengan melakukan wawancara sesuai dengan pedoman wawancara kepada informan dengan menggunakan alat perekam untuk merekam seluruh isi wawancara, serta menggunakan instrumen pendukung antara lain buku catatan, alat perekam berupa audio, kamera untuk mendokumentasikan kegiatan di lapangan dan laptop untuk mengetik hasil penelitian dan rekaman wawancara sehingga berbentuk transkrip wawancara. 


\section{Kesesuaian Penyusunan dan Penyampaian Laporan Keuangan Badan Layanan Umum dengan PSAP Nomor 13}

Penelitian ini menganalisis bagaimana penerapan PSAP Nomor 13 pada penyusunan dan penyampaian laporan keuangan Badan layanan Umum. Sebelum keluar ketentuan PSAP Nomor 13, pengakuan pendapatan dilakukan secara bruto dimana Rumah Sakit menerima keseluruhan pendapatan secara penuh termasuk hak mitra KSO dan kemudian mencatat hak mitra KSO sebagai beban KSO pada Laporan Operasional. Setelah ketentuan PSAP Nomor 13 ini diberlakukan, diatur dalam ketentuan tersebut bahwa pendapatan yang didalamnya ada hak mitra KSO harus dilakukan secara netto dengan mengeluarkan terlebih dahulu hak mitra KSO tersebut. Berdasarkan hasil penelitian ini dapat dijelaskan sebagai berikut:

1. RSUP Prof. R. D. Kandou Manado belum menerapkan PSAP Nomor 13 secara keseluruhan dalam mengakui pendapatan atas Kerjasama Operasional (KSO) yang ada di Rumah Sakit. Penerapan PSAP Nomor 13 baru dilaksanakan untuk pendapatan KSO Parkir sedangkan KSO lainnya belum diberlakukan pengakuan pendapatan netto. KSO parkir dapat dengan mudah menerapkan pengakuan pendapatan netto karena pendapatan diterima langsung oleh pihak mitra dan di awal sudah diadakan pemisahan hak sehingga yang disetorkan ke Rumah Sakit adalah sebesar nilai hak Rumah Sakit.

2. Terdapat banyak jenis Kerjasama Operasional dengan karakteristik yang berbeda-beda di RSUP Prof. Dr. R. D. Kandou Manado antara lain a) KSO yang melibatkan 2 pihak, KSO sewa menyewa, KSO pinjam pakai, KSO yang melibatkan 3 pihak. Perbedaan-perbedaan karakteristik KSO ini pada prakteknya masih menimbulkan ketidakjelasan tentang cara pengakuan pendapatannya sesuai PSAP Nomor 13. Dalam kontrak-kontrak kerjasama antara pihak luar dan Rumah Sakit redaksinya berbunyi Kerjasama Operasional sedangkan secara substansi masih belum jelas apakah sesuai dengan substansi KSO yang dimaksud dalam PSAP Nomor 13.

3. Untuk KSO yang melibatkan pihak ketiga seperti KSO kateterisasi jantung yang melibatkan pihak BPJS-Kesehatan terkait pendapatannya, penerapan PSAP Nomor 13 khususnya pengakuan pendapatan secara netto belum diterapkan dimana kendala yang ditemui adalah kesulitan mengeluarkan hak mitra KSO sebelum diakui sebagai pendapatan Rumah Sakit. Petugas yang terkait penyusunan dan penyampaian laporan keuangan tidak memiliki acuan atau petunjuk teknis yang jelas tentang alur pengakuan pendapatan netto yang melibatkan pihak ketiga.

4. Penerapan PSAP Nomor 13 memberi dampak terhadap pencapaian target realisasi Penerimaan Negara Bukan Pajak (PNBP). Dampak ini disebabkan oleh perbedaan metode pengakuan pendapatan dimana penetapan target pendapatan di awal tahun anggaran ditetapkan dengan memperhitungkan pendapatan secara bruto tetapi pada pengakuan pendapatan menurut PSAP Nomor 13 ditetapkan secara netto, hal ini akan berakibat pada tidak tercapainya target realisasi PNBP.

5. Penerapan PSAP Nomor 13 juga berdampak pada indikator penilaian kinerja. Indikator penilaian kinerja dihitung dengan menggunakan score atas hasil perhitungan rasio-rasio keuangan yang didalamnya terkait perhitungan pendapatan. Nilai-nilai score yang diatur dalam indikator tersebut masih mengacu pada pendapatan secara bruto yang akhirnya bisa menyebabkan hasil penilaian kinerja Rumah Sakit menurun jika menggunakan angka pendapatan netto.

Untuk memaksimalkan pendapatan, Rumah Sakit BLU diberi fleksibilitas dalam operasionalnya, salah satunya yaitu dengan pemanfaatan KSO. Pada kategori KSO ini, seluruh kontrak mengatur bahwa pendapatan atas pelayanan terkait KSO di atas dilakukan bagi hasil sesuai dengan persentase yang telah ditentukan. Dalam pelaksanaannya Rumah Sakit memberikan pelayanan kepada pasien dengan melibatkan pihak-pihak luar di atas yang kemudian pelayanan kepada pasien ini dibayarkan oleh pihak pasien atau pihak ketiga sebagai penjamin antara lain sebagian besar dijamin oleh Badan Penyelenggara Jaminan Sosial Kesehatan (BPJS-Kesehatan). Rumah Sakit mengajukan klaim ke BPJS-Kesehatan atas pelayanan kepada pasien peserta BPJS dan kemudian setelah melalui proses verifikasi, BPJS membayar klaim tersebut langsung ke rekening penerimaan Rumah Sakit. Pada periode tertentu pihak ketiga mengajukan tagihan sesuai dengan ketentuan bagi hasil yang telah diatur dalam masing-masing kontrak. Sebelum pemberlakuan PSAP 13 ini, seluruh nilai pendapatan yang didapatkan Rumah Sakit melalui pembayaran klaim dari BPJS-Kesehatan diakui secara bruto dan disahkan seluruhnya sebagai pendapatan Rumah Sakit. Sedangkan tagihan dari pihak kedua dibayarkan menggunakan mata anggaran keluaran 525113-Beban KSO. Dalam hal ini, ketika PSAP 13 dikeluarkan Rumah Sakit mengalami kesulitan dalam upaya menerapkan PSAP 13 karena pengaturan dalam PSAP 13 tidak mengatur dengan jelas pelaksanaan teknis yang akan dibuat dalam kondisi 
perjanjian kerjasama operasional yang melibatkan pihak ketiga. Ketika rekening penerimaan Rumah Sakit menerima sejumlah uang hasil klaim dari BPJS-Kesehatan dan akan meenjalankan pengakuan pendapatan netto dengan memisahkan nilai hak Rumah Sakit terlebih dahulu dengan tidak mensahkan seluruh nilai yang masuk rekening, hal tersebut dirasa mengandung resiko salah pertanggungjawaban karena tidak adanya regulasi yang mendukung atau tidak adanya petunjuk teknis yang mengatur mekanisme pengakuan pendapatan secara netto dalam hal ini.

Menurut Bambang Sunggono dalam buku Hukum dan kebijakan publik, implementasi kebijakan mempunyai beberapa faktor penghambat, salah satunya yaitu isi kebijakan. Pertama, implementasi kebijakan gagal karena masih samarnya isi kebijakan, maksudnya apa yang menjadi tujuan tidak cukup terperinci, sarana-sarana dan penerapan prioritas, atau program-program kebijakan terlalu umum atau sama sekali tidak ada. Kedua, karena kurangnya ketetapan intern maupun ekstern dari kebijakan yang akan dilaksanakan. Ketiga, kebijakan yang akan diimplementasiakan dapat juga menunjukkan adanya kekurangan-kekurangan yang sangat berarti. Keempat, penyebab lain dari timbulnya kegagalan implementasi suatu kebijakan publik dapat terjadi karena kekurangankekurangan yang menyangkut sumber daya-sumber daya pembantu, misalnya yang menyangkut waktu, biaya/dana dan tenaga manusia.

Menurut Bambang Sunggono dalam buku Hukum dan kebijakan publik, implementasi kebijakan mempunyai beberapa faktor penghambat, dalam hal ini yaitu Informasi. Implementasi kebijakan publik mengasumsikan bahwa para pemegang peran yang terlibat langsung mempunyai informasi yang perlu atau sangat berkaitan untuk dapat memainkan perannya dengan baik. Informasi ini justru tidak ada, misalnya akibat adanya gangguan komunikasi (Sunggono, 1994: 149-153).

Selanjutnya menurut Teori Implementasi Kebijakan George Edward III dalam Agustino (2016:136-141) faktor-faktor yang mendukung implementasi kebijakan, salah satunya yaitu komunikasi. Implementasi akan berjalan efektif apabila ukuran-ukuran dan tujuan-tujuan kebijakan dipahami oleh individu-individu yang bertanggung jawab dalam pencapaian tujuan kebijakan. Kejelasan ukuran dan tujuan kebijakan dengan demikian perlu dikomunikasikan secara tepat dengan para pelaksana. Konsistensi atau keseragaman dari ukuran dasar dan tujuan perlu dikomunikasikan sehingga implementor mengetahui secara tepat ukuran maupun tujuan kebijakan itu. Komunikasi dalam organisasi merupakan suatu proses yang amat kompleks dan rumit. Sumber informasi yang berbeda dapat melahirkan interpretasi yang berbeda pula. Agar implementasi berjalan efektif, siapa yang bertanggungjawab melaksanakan sebuah keputusan harus mengetahui apakah sebuah implementasi dapat terlaksana.

Sesungguhnya implementasi kebijakan harus diterima oleh semua personil dan harus mengerti secara jelas dan akurat mengenai maksud dan tujuan dari sebuah kebijakan. Jika para aktor pembuat kebijakan telah melihat ketidakjelasan spesifikasi kebijakan sebenarnya implementor tidak mengerti apa sesungguhnya yang akan diarahkan. Para implementor kebijakan akan bingung dengan apa yang akan dilakukan sehingga jika dipaksakan tidak akan mendapatkan hasil yang optimal.

\section{Kendala Yang Dihadapi Dalam Penerapan PSAP Nomor 13 di RSUP Prof Dr. R. D. Kandou Manado}

Ada 4 (empat) kendala yang ditemui dalam penerapan PSAP Nomor 13 di RSUP Prof Dr. R. D. Kandou Manado yaitu: 1) kendala regulasi; 2) kendala komunikasI; 3) kendala pengaruh penerapan PSAP Nomor 13 terhadap pencapaian target realisasi PNBP; 4) kendala pengaruh penerapan PSAP Nomor 13 terhadap penilaian kinerja Rumah Sakit.

Kendala pertama yaitu terkait masalah regulasi yang kurang jelas. Pengertian KSO yang belum jelas serta tidak tersedianya aturan tambahan atau kebijakan atau petunjuk teknis yang jelas tentang alur pengakuan pendapatan hasil KSO menyebabkan pelaksana tidak memiliki pedoman atau payung hukum yang pasti dalam melaksanakan penerapan PSAP Nomor 13 tersebut. Menurut Bambang Sunggono dalam buku Hukum dan kebijakan publik, implementasi kebijakan mempunyai beberapa faktor penghambat, salah satunya yaitu isi kebijakan. Pertama, implementasi kebijakan gagal karena masih samarnya isi kebijakan, maksudnya apa yang menjadi tujuan tidak cukup terperinci, sarana-sarana dan penerapan prioritas, atau program-program kebijakan terlalu umum atau sama sekali tidak ada. Kedua, karena kurangnya ketetapan intern maupun ekstern dari kebijakan yang akan dilaksanakan. Ketiga, kebijakan yang akan diimplementasiakan dapat juga menunjukkan adanya kekurangan-kekurangan yang sangat berarti. Keempat, penyebab lain dari timbulnya kegagalan implementasi suatu kebijakan publik dapat terjadi karena kekurangan-kekurangan yang menyangkut 
sumber daya-sumber daya pembantu, misalnya yang menyangkut waktu, biaya/dana dan tenaga manusia.

Kendala kedua yaitu komunikasi dari Kementerian Kesehatan RI kepada pihak Rumah Sakit yang mengakibatkan kurangnya sumber daya manusia yang memahami dan mendapatkan informasi mengenai bagaimana penerapan PSAP ini. Unit yang sudah terpapar dengan informasi ini baru sebatas unit akuntansi saja sedangkan unit terkait lainnya seperti perbendaharaan, tim telaah KSO dan bagian Anggaran belum mendapatkan pelatihan atau sosialisasi terkait PSAP Nomor 13.

Menurut Teori Implementasi Kebijakan George Edward III dalam Agustino (2016:136-141) faktor-faktor yang mendukung implementasi kebijakan, salah satunya yaitu komunikasi. Implementasi akan berjalan efektif apabila ukuran-ukuran dan tujuan-tujuan kebijakan dipahami oleh individuindividu yang bertanggung jawab dalam pencapaian tujuan kebijakan. Kejelasan ukuran dan tujuan kebijakan dengan demikian perlu dikomunikasikan secara tepat dengan para pelaksana. Konsistensi atau keseragaman dari ukuran dasar dan tujuan perlu dikomunikasikan sehingga implementor mengetahui secara tepat ukuran maupun tujuan kebijakan itu. Komunikasi dalam organisasi merupakan suatu proses yang amat kompleks dan rumit. Sumber informasi yang berbeda dapat melahirkan interpretasi yang berbeda pula. Agar implementasi berjalan efektif, siapa yang bertanggungjawab melaksanakan sebuah keputusan harus mengetahui apakah sebuah implementasi dapat terlaksana. Sesungguhnya implementasi kebijakan harus diterima oleh semua personil dan harus mengerti secara jelas dan akurat mengenai maksud dan tujuan dari sebuah kebijakan. Jika para aktor pembuat kebijakan telah melihat ketidakjelasan spesifikasi kebijakan sebenarnya implementor tidak mengerti apa sesungguhnya yang akan diarahkan. Para implementor kebijakan akan bingung dengan apa yang akan dilakukan sehingga jika dipaksakan tidak akan mendapatkan hasil yang optimal.

Kendala ketiga yaitu adanya pengaruh penerapan PSAP Nomor 13 terhadap target realisasi Penerimaan Negara Bukan Pajak (PNBP). Target merupakan salah satu dari rencana yang telah diatur dan disusun dalam waktu tertentu dengan analisis tertentu. Target PNBP yang dibuat menjadi buah penghitungan atau penetapan PNBP yang akan diterima dalam 1 (satu) tahun akan datang. Mekanisme penyusunan target dilakukan secara berjenjang berdasarkan pengklasifikasian organisasi mulai tingkat Satuan kerja/UPT, Unit Eselon I sampai dengan Kementerian/Lembaga dengan dikoordinsaikan oleh Biro Perencanaan dan Keuangan masing-masing Kementerian/Lembaga. Penyusunan ini harus disusun berdasarkan azas realistis dan reliable. Target PNBP disusun dengan menggunakan formula volume $\mathrm{x}$ tarif per jenis PNBP sesuai dengan PP Tarif PNBP yang ditetapkan oleh Menteri Keuangan. Penyusunan yang dibuat harus berdasar pada Akun PNBP yang mengacu kepada Peraturan Menteri Keuangan tentang Bagan Akun Standar. Pada penetapan target PNBP, perkiraan pendapatan dihitung berdasarkan perhitungan pendapatan bruto sedangkan menurut PSAP Nomor 13 pendapatan diakui secara netto. Ketika Rumah Sakit menerapkan pengakuan pendapatan secara netto maka target realisasi PNBP tidak akan tercapai. Karena pendapatan KSO jumlahnya cukup besar sehingga sangat berpengaruh pada pencapaian target pendapatan akhir. Hal ini menjadi kendala dalam penerapan PSAP Nomor 13.

Kendala keempat yaitu pengaruh penerapan PSAP Nomor 13 terhadap penilaian kinerja Rumah Sakit. Konsep pengakuan pendapatan yang diterapkan oleh Rumah Sakit sebelum adanya PSAP Nomor 13 yaitu secara bruto. Sehingga pada saat Rumah Sakit menerapkan PSAP Nomor 13 yang mencatat pendapatan secara netto, pasti indikator kinerja yang sebelumnya secara bruto, sekarang berubah menjadi netto dan hal ini pasti berpengaruh besar. Disamping itu, pertanggungjawaban atas beban juga pasti berpengaruh, seperti yang dijelaskan oleh informan-informan dalam hasil wawancara berikut. Hal ini karena penilaian kinerja Rumah Sakit yang disajikan dalam laporan kinerja memiliki ketentuan dan rumus-rumus penilaian kinerja yang nilainya didapat dari pencatatan secara bruto baik di laporan operasional maupun laporan realisasi anggaran. Sehingga apabila menerapkan pencatatan pendapatan secara netto berdasarkan PSAP Nomor 13, tentu penilaian kinerja akan turun dan akan berpengaruh juga pada bagian anggaran dan bahkan berpengaruh sampai pada status BLU Rumah Sakit yang menurun dari indicator penilaian yang ada Peraturan Direktur Jenderal Perbendaharaan Nomor PER-36/PB/2016 tentang Pedoman Penilaian Kinerja Badan Layanan Umum Bidang Layanan Kesehatan mengatur tentang penilaian kinerja pada aspek pelayanan, dan aspek keuangan. Penilaian aspek keuangan adalah penilaian kinerja BLU berdasarkan analisis data laporan keuangan BLU dan kepatuhan terhadap peraturan perundang-undangan mengenai pengelolaan keuangan BLU. Untuk menentukan hasil penilaian kinerja BLU, dihitung menggunakan score dimana total score hasil penjumlahan dari nilai aspek keuangan dan aspek pelayanan. 
Penilaian aspek keuangan meliputi rasio keuangan dan kepatuhan pengelolaan keuangan BLU. Rasio Keuangan digunakan untuk membandingkan data keuangan yang terdapat pada pos Laporan Keuangan BLU, meliputi pengukuran terhadap rasio kas, rasio lancar, periode penagihan piutang, perputaran aset tetap, imbalan atas aset tetap, imbalan ekuitas, perputaran persediaan, rasio PNBP terhadap biaya operasional, rasio biaya subsidi. Hasil penilaian kinerja BLU ditentukan berdasarkan total score yang diperoleh BLU. Hasil penilaian tersebut dikelompokkan dalam kriteria baik, sedang dan buruk. Perhitungan atas pengukuran rasio keuangan di atas untuk rumus terkait pendapatan belum menyesuaikan dengan pengakuan pendapatan netto sesuai PSAP Nomor 13, hal ini bisa berdampak pada hasil perhitungan yang dapat mempengaruhi score dalam penentuan hasil perhitungan kinerja keuangan Rumah Sakit. Implementasi itu merupakan tindakan-tindakan yang dilakukan oleh pemerintah untuk mencapai tujuan yang telah di tetapkan dalam suatu keputusan kebijakan. Akan tetapi pemerintah dalam membuat kebijakan juga harus mengkaji terlebih dahulu apakah kebijakan tersebut dapat memberikan dampak yang buruk atau tidak bagi masyarakat. Hal tersebut bertujuan agar suatu kebijakan tidak bertentangan dengan implementor apalagi sampai merugikan publik atau implementor. Mazmanian dan Sebastiar juga mendefinisikan bahwa implementasi adalah pelaksanaan keputusan kebijakan dasar, biasanya dalam bentuk undang-undang, namun dapat pula berbentuk perintah-perintah atau keputusan-keputusan eksekutif yang penting atau keputusan badan peradilan (Mazmanian dan Sebastiar dalam Wahab, 2004:68). Implementasi menurut Mazmanian dan Sebastier merupakan pelaksanaan kebijakan dasar berbentuk undang-undang juga berbentuk perintah atau keputusan-keputusan yang penting atau seperti keputusan badan peradilan. Proses implementasi ini berlangsung setelah melalui sejumlah tahapan tertentu seperti tahapan pengesahan undang-undang, kemudian output kebijakan dalam bentuk pelaksanaan keputusan dan seterusnya sampai perbaikan kebijakan yang bersangkutan.

Kebijakan mengandung suatu unsur tindakan-tindakan untuk mencapai tujuan. Umumnya tujuan tersebut ingin dicapai oleh seseorang, kelompok ataupun pemerintah. Kebijakan tentu mempunyai hambatan-hambatan pada pelaksanaannya tetapi harus mencari peluang-peluang untuk mewujudkan tujuan yang diinginkan. Kebijakan mengandung suatu unsur tindakan untuk mencapai tujuan dan umumnya tujuan tersebut ingin dicapai oleh seseorang, kelompok ataupun pemerintah. Hal tersebut berarti kebijakan tidak boleh bertentangan dengan nilai-nilai dan praktik-praktik sosial yang ada dalam masyarakat. Apabila kebijakan berisi nilai-nilai yang bertentangan dengan nilai-nilai yang hidup dalam masyarakat, maka kebijakan tersebut akan mendapat kendala ketika di implementasikan. Sebaliknya suatu kebijakan harus mampu mengakomodasikan nilai-nilai dan praktik-praktik yang hidup dan berkembang dalam masyarakat.

\section{Upaya Memperbaiki Pengelolaan Aset Daerah Yang Lebih Baik di Kabupaten Bolaang Mongondow}

Untuk menyelesaikan masalah dan kendala terkait penerapan PSAP Nomor 13 pada rumah sakit Prof.Dr.R.D Kandou, maka upaya komunikasi perlu dilakukan. Komunikasi merupakan suatu langkah yang dilakukan oleh pihak Rumah Sakit Prof. R. D. Kandou sebagai salah satu upaya dalam mengatasi kendala penerapan PSAP Nomor 13 seperti melakukan pertemuan-pertemuan baik itu di bidang akuntansi maupun anggaran, mengadakan sosialisasi ke bidang-bidang yang terkait, serta turut memberikan usulan, masukan atau ide pemikiran yang terjadi di lapangan untuk disampaikan kepada pihak Kementrian Kesehatan. Upaya komunikasi ini juga tidak hanya dilakukan oleh pihak Rumah Sakit, namun juga dilakukan oleh Pihak Kementrian Kesehatan dalam menindaklanjuti keluhan dan kendala yang dihadapi oleh Pihak Rumah Sakit seperti mengeluarkan Permenkes No. 36 Tahun 2017, mengadakan pembahasan dengan KSAP dan Kementerian Keuangan dan terus mengadakan konsultasi dengan Kementrian Keuangan dalam hal mengeluarkan kebijakan-kebijakan pendukung terkait penerapan PSAP Nomor 13 untuk pengakuan pendapatan KSO Rumah Sakit. Mengingat bahwa Rumah Sakit bukan merupakan pengambil kebijakan maka upaya yang dapat dilakukan adalah komunikasi. Secara rinci dapat dijelaskan bahwa upaya-upaya yang dapat dilakukan dalam mengatasi kendala yang ada adalah sebagai berikut.

1. Untuk kendala "tidak adanya regulasi yang mendukung implementasi PSAP 13, satuan kerja tersebut membutuhkan tambahan kebijakan, aturan jelas tentang definisi KSO, petunjuk teknis lebih jelas secara rinci dalam mengenai proses penyusunan sampai dengan laporan pertanggungjawaban" mengingat RSUP Prof Dr. R. D. Kandou Manado sebagai implementor kebijakan dan bukan bertindak sebagai pembuat atau pengambil kebijakan maka upaya yang dapat dilakukan adalah RSUP Prof. Dr. R. D. Kandou Manado melakukan evaluasi dan 
menginventarisir hal-hal teknis di lapangan yang perlu diketahui para pengambil kebijakan atau pun pembuat regulasi dan disampaikan dalam bentuk laporan dan usulan kepada Kementerian Kesehatan RI melalui Direktorat Jenderal Pelayanan Kesehatan.

2. Untuk kendala "kurangnya komunikasi berupa belum adanya informasi yang jelas dari kemenkes kepada pihak Rumah Sakit yang berpengaruh terhadap pemahaman SDM sebagai pelaksana dalam implementasi PSAP 13" RSUP Prof. Dr. R. D. Kandou Manado telahu mengajukan permohonan pelaksanaan sosialisasi dan pelatihan bagi SDM pelaksana terkait implementasi PSAP 13.

3. Untuk kendala "bahwa penerapan PSAP 13 ini berpengaruh pada pencapaian Target Realisasi Penerimaan Negara Bukan Pajak dimana penetapan targetnya ditetapkan berdasarkan pendapatan bruto sedangkan PSAP 13 mengatur pengakuan pendapatan secara netto maka upaya yang dilakukan oleh RSUP Prof.Dr.R.D.Kandou Manado menyampaikan adanya pengaruh penerapan PSAP 13 terhadap pencapaian target realisasi PNBP kemudian diteruskan oleh pihak eksternal yaitu Direktorat Jenderal Pelayanan Kesehatan kepada para pembuat kebijakan atau pembuat regulasi agar meninjau kembali penetapan target PNBP untuk disesuaikan dengan ketentuan yang diatur dalam PSAP 13 maupun meninjau kembali ketentuan PSAP 13 itu sendiri.

4. Untuk kendala "bahwa penerapan PSAP 13 ini berpengaruh pada penilaian kinerja keuangan Badan Layanan Umum dimana indikator penilaian beserta scorenya disusun dengan mengacu pada rumus-rumus pendapatan netto sedangkan penerapan PSAP 13 mengakui pendapatan secara netto yang bisa mengakibatkan penilaian kinerja keuangan menurun" RSUP Prof.Dr.R.D.Kandou Manado telah berupaya menyampaikan adanya pengaruh penerapan PSAP 13 terhadap penilaian kinerja BLU untuk diteruskan oleh pihak eksternal yaitu Direktorat Jenderal Pelayanan Kesehatan untuk diteruskan kepada para pembuat kebijakan atau pembuat regulasi agar meninjau kembali pedoman penilaian kinerja BLU untuk disesuaikan dengan ketentuan yang diatur dalam PSAP 13 maupun meninjau kembali ketentuan PSAP 13 itu sendiri.

Menurut Teori Implementasi Kebijakan George Edward III dalam Agustino (2016:136-141) faktor-faktor yang mendukung implementasi kebijakan, salah satunya adalah komunikasi. Implementasi akan berjalan efektif apabila ukuran-ukuran dan tujuan-tujuan kebijakan dipahami oleh individu-individu yang bertanggung jawab dalam pencapaian tujuan kebijakan. Kejelasan ukuran dan tujuan kebijakan dengan demikian perlu dikomunikasikan secara tepat dengan para pelaksana. Konsistensi atau keseragaman dari ukuran dasar dan tujuan perlu dikomunikasikan sehingga implementor mengetahui secara tepat ukuran maupun tujuan kebijakan itu. Komunikasi dalam organisasi merupakan suatu proses yang amat kompleks dan rumit. Sumber informasi yang berbeda dapat melahirkan interpretasi yang berbeda pula. Agar implementasi berjalan efektif, siapa yang bertanggungjawab melaksanakan sebuah keputusan harus mengetahui apakah sebuah implementasi dapat terlaksana.

Komunikasi memegang peranan penting bagi berlangsungnya koordinasi implementasi kebijakan. Menurut Hogwood dan Gunn yang dikutip oleh Wahab bahwa koordinasi bukanlah sekedar menyangkut persoalan mengkomunikasikan informasi ataupun membentuk struktur-struktur administrasi yang cocok melainkan menyangkut pula persoalan yang lebih mendasar, yaitu praktik pelaksanaan kebijakan (Hogwood dan Gunn dalam Wahab, 2004:77). Berdasarkan teori tersebut maka Semakin baik koordinasi komunikasi diantara pihak-pihak yang terlibat dalam suatu proses implementasi, maka terjadinya kesalahan-kesalahan akan sangat kecil untuk terjadi dan begitu pula sebaliknya.

Selain komunikasi faktor-faktor lain yang mendukung implementasi menurut teori Implementasi Kebijakan George Edward III dalam Agustino, (2016:137) adalah sumber daya, disposisi atau sikap dan struktur birokrasi. Mengingat bahwa RSUP Prof. Dr. R. D. Kandou Manado adalah satuan kerja yang bertindak sebagai pelaksana kebijakan dan bukan pengambil kebijakan maka hal utama yang muncul dalam upaya penerapan PSAP Nomor 13 dalam penyusunan dan penyampaian laporan keuangan adalah komunikasi sedangkan ketiga faktor lainnya menurut pengamatan dari peneliti tidak menimbulkan kendala berarti dalam penerapan PSAP Nomor 13.

\section{Penutup}

Kesimpulan dalam penelitian ini adalah: 1) Penyajian Laporan Keuangan di RSUP Prof. Dr. R. D. Kandou Manado telah menerapkan PSAP Nomor 13 namun belum secara keseluruhan lebih 
khusus dalam mengakui pendapatan netto atas Kerjasama Operasional (KSO) yang ada di Rumah Sakit. KSO yang telah menerapkan PSAP Nomor 13 yaitu KSO Parkir dimana pengakuan pendapatannya telah diakui secara netto dengan terlebih dahulu mengeluarkan bagian pendapatan yang merupakan hak mitra. KSO juga belum menerapkan PSAP Nomor 13 yaitu jenis KSO bagi hasil yang melibatkan pihak ketiga yaitu BPJS-Kesehatan antara lain KSO Alat Kateterisasi Jantung. Keterlibatan pihak BPJS-Kesehatan dalam alur pendapatan menyulitkan pihak rumah sakit untuk mengeluarkan pendapatan yang merupakan hak mitra KSO, dimana pembayaran klaim dari BPJS-Kesehatan ditransfer langsung ke rekening Rumah Sakit tanpa melalui mitra KSO; 2) Kendala yang ditemui dalam penerapan PSAP Nomor 13 yaitu belum adanya regulasi yang jelas tentang pengertian KSO, belum tersedianya aturan tambahan atau petunjuk teknis yang lebih jelas mengatur tentang alur pengakuan pendapatan netto lebih khusus bagi KSO yang melibatkan pihak ketiga yaitu BPJSKesehatan. Kendala tidak tersedianya petunjuk teknis ini menyebabkan penerapan PSAP Nomor 13 tidak bisa dilaksanakan secara penuh. Kendala lainnya yang dihadapi juga kurangnya komunikasi dari Kementerian Kesehatan RI kepada Rumah Sakit yang mengakibatkan kurangnya SDM yang memahami dan adanya pengaruh penerapan PSAP Nomor 13 yang berdampak pada target realisasi PNBP dan penilaian kinerja Rumah Sakit.; 3) Upaya untuk menerapkan PSAP Nomor 13 dilakukan oleh pihak RSUP Prof. Dr. R. D. Kandou Manado dan pihak Kementerian Kesehatan RI dalam hal ini oleh Direktorat Pelayanan Kesehatan. Sebagai pelaksana kebijakan upaya yang telah dilakukan oleh pihak RSUP Prof. Dr. R. D. Kandou Manado adalah mengkomunikasikan masukan, ide pemikiran tentang KSO kepada para pembuat kebijakan tentang kendala yang ada di lapangan dan memberikan masukan tentang karakteristik KSO yang bervariasi yang ada di lapangan sehingga para pembuat kebijakan memiliki pengetahuan tentang pelaksanaan teknis di lapangan. Kementerian Kesehatan RI melalui Direktorat Jenderal Pelayanan Kesehatan telah berupaya mengeluarkan Permenkes 36 Tahun 2017 untuk menjawab kebutuhan satuan kerja dibawahnya tentang Kerjasama Operasioanal dan dalam beberapa kesempatan telah berupaya berkoordinasi dengan Komite Standar Akuntansi Pemerintahan (KSAP) dan Kementerian Keuangan RI untuk menjawab kebutuhan di lapangan agar mengeluarkan kebijakan-kebijakan pendukung terkait penerapan PSAP Nomor 13.

Saran yang dapat diberikan dari penelitian ini yaitu: 1) RSUP Prof. Dr. R. D. Kandou melalui Kementerian Kesehatan RI perlu memberikan gambaran yang jelas tentang KSO yang ada di lapangan, untuk dipertimbangkan oleh KSAP dan Kementerian Keuangan tentang karakteristik KSO yang beraneka ragam sehingga Kementerian Kesehatan RI, Kementerian Keuangan RI dan KSAP dapat mengeluarkan regulasi yang jelas mengenai pengertian KSO agar satu persepsi dalam penerapannya; 2) RSUP Prof Dr. R. D. Kandou Manado perlu menyampaikan secara tertulis permintaan petunjuk teknis yang lebih jelas mengatur tentang alur pengakuan pendapatan netto lebih khusus bagi KSO seperti KSO Alat Kateterisasi Jantung yang melibatkan pihak ketiga yaitu BPJS-Kesehatan agar penerapan PSAP Nomor 13 dapat dilaksanakan lengkap dengan pedoman dan payung hukum yang jelas; 3) Kementerian Kesehatan RI perlu melaksanakan pelatihan dan sosialisasi khusus PSAP Nomor 13 kepada semua unit yang terkait dalam penerapan PSAP Nomor 13 baik unit akuntansi, perbendaharaan maupun unit terkait lainnya; 4) RSUP Prof. Dr. R. D. Kandou perlu menyampaikan kepada Kementerian Kesehatan tentang adanya dampak penerapan PSAP Nomor 13 ini terhadap pencapaian target realisasi PNBP dan dampak penerapan PSAP Nomor 13 terhadap indikator penilaian kinerja Rumah Sakit; 5) RSUP Prof. Dr. R. D. Kandou Manado perlu melakukan evaluasi kembali atas KSO-KSO yang ada di Rumah Sakit dan memeriksa kembali kontrak-kontrak KSO dan melakukan revisi atas kontrak-kontrak yang belum mengatur hal-hal terkait PSAP Nomor 13.

\section{DAFTAR PUSTAKA}

Agustino, Leo. 2016. Dasar-dasar Kebijakan Publik. Bandung: Alfabeta.

Ardy Wilther Sangian. 2015. Analisis Penerapan Akuntansi Berdasarkan PSAP (PP No.24 Tahun 2005) Atas Penyusunan Laporan Keuangan Pemerintah Provinsi Sulawesi Utara. Jurnal EMBA 421 Vol.3 No.4 Desember 2015, Hal. 413-421. Universitas Sam Ratulangi.

Hesti Irna Rahmawati. 2016. Analisis Kesiapan Desa Dalam Implementasi Penerapan UU Nomor 6 Tahun 2014 Tentang Desa (Studi Pada Delapan Desa di Kabupaten Sleman). Halaman 305313. Fakultas Ekonomi. Universitas Cokroaminoto Yogyakarta.

Indah Fitra Ramadani. 2016. Analisis Penerapan Sistem Penjualan Kredit Pada PT Unity Di Samarinda. E-Journal Ilmu Administrasi Bisnis, Volume 4, Nomor 3, 2016: 841-853. Fakultas Ilmu Sosial dan Ilmu Politik, Universitas Mulawarman. 
Komsiyatun. 2017. Implementasi Pernyataan Standar Akuntansi pemerintahan (PSAP) Nomor 12 dalam laporan operasional Pemerintah kota Surakarta tahun 2015. Tesis. Universitas Sebelas Maret. Surakarta.

Lilya Andriani, Anantawikrama Tungga Atmadja, dan Ni Kadek Sinarwati. 2014. Analisis Penerapan Pencatatan Keuangan Berbasis Sak Etap Pada Usaha Mikro Kecil Menengah (UMKM) (Sebuah Studi Intrepetatif Pada Peggy Salon).eJournal S1 Akuntansi. Vol. 2 No: 1 Tahun 2014. Halaman 1-12. Universitas Pendidikan Ganesha.

Maulida Alfi Lofiana Sa'diya, Siti Ragil Handayani, dan Idris Effendy. 2016. Analisis Penerapan Peraturan Pemerintah Nomor 46 Tahun 2013 Untuk Wajib Pajak Yang Memiliki Peredaran Bruto Tertentu (Studi Pada KPP Pratama Malang Utara). Jurnal Perpajakan (JEJAK). Vol. 10 No. 1 2016. Halaman 1-7. Universitas Brawijaya.

Mokhamad, Irawan. 2016. Penerapan Pernyataan Standar Akuntansi Pemerintah Nomor 02 Tentang Laporan Realisasi Anggaran Dalam Peraturan Pemerintah Nomor 71 Tahun 2010 dan Permendagri Nomor 64 Tahun 2013 (Studi Kasus Pada Pemerintah Kabupaten Mojokerto). Jurnal Riset Mahasiswa Akuntansi. Vol. 4, No. 2 Fakultas Ekonomi. Universitas Kanjuruhan. Malang.

Republik Indonesia. 2005. Peraturan Pemerintah Nomor 23 Tahun 2005 Tentang Pengelolaan Keuangan Badan Layanan Umum. Jakarta. . 2010. Peraturan Pemerintah Nomor 71 Tahun 2010 Tentang Standar Akuntansi Pemerintahan. Jakarta. 2014. Peraturam Menteri Keuangan Nomor 270/PMK.05/2014 tentang Standar Akuntansi Pemerintah Berbasis Akrual. Jakarta. 2015. Peraturam Menteri Keuangan Nomor 220/PMK.05/2015 tentang Sistem Akuntansi dan Pelaporan Keuangan Badan Layanan Umum. Jakarta. . 2017. Peraturam Menteri Keuangan Nomor 42/PMK.05/2017 tentang Perubahan Atas Peraturan Menteri Keuangan Nomor 220/PMK.05/2015. Jakarta. .2012. Peraturan Pemerintah Nomor 74 Tahun 2012 Tentang Perubahan Peraturan Pemerintah Nomor 23 Tahun 2005 Tentang Pengelolaan Keuangan Badan Layanan Umum. Jakarta.

.2015. Peraturam Menteri Keuangan Nomor 217/PMK.05/2015 tentang Pernyataan Standar Akuntansi Pemerintah tentang Penyajian Laporan Keuangan Badan Layanan Umum. Jakarta.

Rima Niasari. 2016. Implementasi PSAP 07 Tentang Akuntansi Aset Tetap Basic Akrual pada Dinas Pendapatan Pengelolaan Keuangan dan Aset Daerah Istimewa Yogyakarta Tahun 2015. Jurnal Ekonomi dan Bisnis. Volume 8 Nomor 03. Halaman 58-71. Universitas Gajah Mada. Yogyakarta.

Sugiyono. 2015. Memahami Penelitian Kualitatif. Alfabeta. Bandung.

Sunggono, Bambang. 1994. Hukum Kebijakan Publik, Sinar Grafika, Jakarta.

Wahab Abdul, Solichin. 2005. Analisis Kebijaksanaan dari Formulasi ke Implementasi Kebijaksanaan Negara. Jakarta:Bumi Aksara.

Wildana, Alimin Maidin, Pasinringi. 2012. Study of the implementation of the application of public service agencies in RS. DR Tadjuddin Chalid Makassar in 2012. Jurnal ilmiah. Volume 17 No. 2. Halaman 1-12. Universitas Hasanudin. 